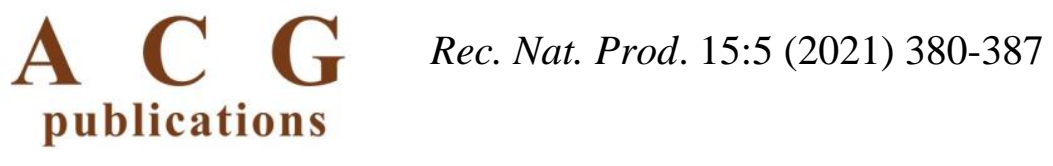

\title{
Isolation and Characterization of Glycosidic Tyrosinase Inhibitors from Typhonium giganteum Rhizomes
}

\author{
Penghua Shu $\oplus^{1 *}$, Huiqing Zhu $\oplus^{1}$, Wanrong Liu $\oplus^{1}$, Lingxiang Zhang $\oplus^{1}$, \\ Junping Li $\odot{ }^{1}$, Mengzhu Yu $\oplus^{1}$, Yingying Fei $\oplus^{1}$, Shujing Cai $\odot{ }^{1}$, \\ Ruihua Li $\odot^{1}$, Xialan Wei $\bigodot^{2}$, Wenhan $\mathrm{Yi}^{3}$ and Fugang Xiao $\oplus^{1 *}$ \\ ${ }^{1}$ Food and Pharmacy College, Xuchang University, Xuchang, Henan 461000, P. R. China \\ ${ }^{2}$ School of Information Engineering, Xuchang University, Xuchang, Henan 461000, P. R. China \\ ${ }^{3}$ Communist Youth League Committee, Xuchang University, Xuchang, Henan 461000, P. R. China
}

(Received February 15, 2021; Revised March 02, 2021; Accepted March 05, 2021)

\begin{abstract}
A new hydrocinnamoyl glucoside, 1-O-(4-hydroxyhydrocinnamoyl)- $\beta$-D-glucopyranose (1), together with fifteen known glycosides, including two phenylethanoid glycosides (2-3), two cinnamoyl glycosides (4-5), six phenolic glycosides (6-11), one lignan glycoside (12) and four megastigmane glycosides (13-16) were isolated from a $95 \% \mathrm{EtOH}$ extract of the Typhonium giganteum rhizomes. The sixteen glycosides were structurally characterized by NMR, HRESIMS, enzymatic hydrolysis and comparison with literature. Upon evaluating inhibitory activities of compounds 1-16 against mushroom tyrosinase at $25 \mu \mathrm{M}$, compounds $\mathbf{1 0}$ and 11 exhibited obvious inhibitory activities, with \%inhibition values of $20.94 \pm 0.59 \%, 23.28 \pm 1.09 \%$, respectively, with arbutin used as the positive control $(26.21 \pm 0.58 \%)$.
\end{abstract}

Keywords: Typhonium giganteum; tyrosinase inhibitor; glycoside; arbutin. (C) 2021 ACG Publications. All rights reserved.

\section{Introduction}

Typhonium giganteum rhizomes, also known as Typhonii Rhizoma, are widely utilized in Traditional Chinese Medicines to treat tetanus, stroke and epilepsia [1]. Previous investigations have shown that crude extracts of $T$. giganteum rhizomes possess tyrosinase inhibitory activity [2-3], and many glycosides have been isolated from various parts of this plant [4-6]. In search for potential tyrosinase inhibitors from natural sources [7-9], our investigation on an EtOH extract of the $T$. giganteum rhizomes has led to the isolation of one new and fifteen known compounds. Two of them showed strong tyrosinase inhibitory activities [10]. In continuing our study on the constituents of the EtOH extract of $T$. giganteum rhizomes, we have isolated one new and fifteen known glycosidic compounds (Figure 1). During the subsequent antityrosinase assay, glycosides $\mathbf{1 0}$ and $\mathbf{1 1}$ showed strong inhibitory activities similar to that of arbutin. Here, we describe the characterization of these glycosides and the evaluation of their inhibitory effects against mushroom tyrosinase.

\footnotetext{
*Corresponding author: E-Mail: shupenghua@yeah.net; Phone:086-374-2968812 Fax: 086-374-2968812

*Corresponding author: E-Mail: xfug@163.com; Phone: 086-374-2968812 Fax: 086-374-2968812
} 


<smiles>COc1cc(CCOC2OC(O)C(O)C(O)CC2(O)CO)ccc1O</smiles>

2<smiles>COc1cc(/C=C/C(=O)OC2OC(CO)C(O)C(O)C(O)C2O)ccc1O</smiles>

5<smiles>C=Cc1ccc(OC(O)C(O)C(CO)C(O)CO)c(OC)c1</smiles>

8<smiles>COc1cc(CCOC2OC(CO)C(O)C(O)C(O)C2O)cc(OC)c1O</smiles><smiles>COc1cc(/C=C/CO)ccc1OC1OC(O)C(O)C(O)C1O</smiles>

6<smiles>COc1cc(CO)ccc1OC1OCC(O)C(O)C(O)O1</smiles>

9

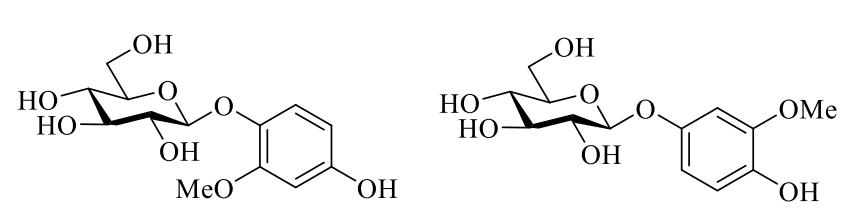

10

11<smiles>COc1cc([C@@H]2OC[C@@H]3[C@H]2CO[C@H]3c2ccc(OC3OC(O)C(CO)C(O)C3O)c(OC)c2)ccc1O</smiles>

12<smiles>CC(=O)/C=C/[C@@]1(O)[C@@H](C)[C@@H](OC(OCC(O)CO)C(O)CO)[C@H](O)C[C@]1(C)CO</smiles>

13<smiles>CC1=CC(=O)CC(C)(C)[C@H]1CC[C@H](C)O[C@H](O)[C@H](O)[C@H](O)[C@H](O)CO</smiles>

14<smiles>CC1=CC(=O)CC(C)(C)[C@@]1(O)/C=C/[C@H](C)[C@H](O)[C@H](O)[C@H](O)[C@H](O)CO</smiles>

15<smiles>CC(=O)CC[C@H]1[C@@H](C)C[C@H](OC2OC(O)C(O)C(O)C(O)C2O)CC1(C)C</smiles>

16

Figure 1. Chemical structures of compounds 1-16

\section{Materials and Methods}

\subsection{General Experimental Procedures}

Column chromatography (CC) was performed using silica gel (Qingdao Marine Chemical Inc., China), Sephadex LH-20 (GE Healthcare Bio-Sciences AB, Sweden) and RP-C18 (50 $\mu$ m, Fuji Silysia Chemical Ltd., Japan). TLC was performed with silica gel 60 F254 (Yantai Chemical Industry Research Institute). The spots on TLC were visualized by warming $10 \% \mathrm{H}_{2} \mathrm{SO}_{4}\left(10 \% \mathrm{H}_{2} \mathrm{SO}_{4}\right.$ in ethanol) sprayed plates on a hot plate. NMR spectra were recorded on a Bruker AM-400 spectrometer (400 $\mathrm{MHz}$ ), and the ${ }^{1} \mathrm{H}$ and ${ }^{13} \mathrm{C} \mathrm{NMR}$ chemical shifts were referenced to the solvent or solvent impurity peaks for $\mathrm{CD}_{3} \mathrm{OD}$ at $\delta_{\mathrm{H}} 3.31$ and $\delta_{\mathrm{C}} 49.15$. HRESIMS spectra were carried out on a Bruker micrOTOF II spectrometer. Optical rotations were determined on a Rudolph Autopol IV polarimeter. UV and IR spectra were determined using Puxi TU-1950 and FTIR-650 instruments, respectively. 
Isolation and characterization glycosidic tyrosinase inhibitors

\subsection{Plant Material}

The rhizomes of Typhonium giganteum were collected in Yuzhou, P. R. China, in September 2020 and authenticated by Prof. Lin Yang at Lanzhou University of Technology. The specimen (SPH2020A) was stored in Food and Pharmacy College, Xuchang University.

\subsection{Extraction and Isolation}

The air-dried rhizomes of Typhonium giganteum $(6.4 \mathrm{~kg})$ were extracted with $95 \% \mathrm{EtOH}(3 \times 35$ $\mathrm{L}$, room temperature) to yield a crude extract $(347 \mathrm{~g})$, which was suspended in warm $\mathrm{H}_{2} \mathrm{O}$ and partitioned by $\mathrm{CH}_{2} \mathrm{Cl}_{2}$ and $n-\mathrm{BuOH}$. The $n-\mathrm{BuOH}$ fraction $(90.2 \mathrm{~g})$ was subjected to silica gel CC eluted by $\mathrm{CH}_{2} \mathrm{Cl}_{2}-\mathrm{MeOH}$ (50:1 to 2:1) to give eleven fractions F1-F11. The fraction F5 (3.1 g, eluted by $\left.\mathrm{CH}_{2} \mathrm{Cl}_{2}-\mathrm{MeOH} 25: 1\right)$ was subsequently purified using $\mathrm{RP}-\mathrm{C}_{18} \mathrm{CC}\left(\mathrm{MeOH}-\mathrm{H}_{2} \mathrm{O}, 65: 35\right.$ to 100:0) to afford compounds $7(5.4 \mathrm{mg})$ and $\mathbf{8}(6.7 \mathrm{mg})$. The fraction F6 (2.6 g, eluted by $\left.\mathrm{CH}_{2} \mathrm{Cl}_{2}-\mathrm{MeOH} 20: 1\right)$ was further separated using Sephadex LH-20 column (MeOH) to give compounds $\mathbf{1 2}(10.3 \mathrm{mg})$ and $\mathbf{1}$ (20.5 mg). The fraction F7 (17.5 g, eluted by $\left.\mathrm{CH}_{2} \mathrm{Cl}_{2}-\mathrm{MeOH} 15: 1\right)$ was passed through a RP-C ${ }_{18} \mathrm{CC}$ using $\mathrm{MeOH}-\mathrm{H}_{2} \mathrm{O}$ (20:80 to 100:0) as eluents to give six subfractions (F7-1 to F7-6). The subfraction F7-1 was purified on the silica gel CC to give compounds $13(3.8 \mathrm{mg})$ and $15(5.6 \mathrm{mg})$. The subfraction F7-3 was chromatographed by RP-C $\mathrm{C}_{18} \mathrm{CC}\left(\mathrm{MeOH}-\mathrm{H}_{2} \mathrm{O}, 35: 65\right)$ to obtain compounds 4 $(5.7 \mathrm{mg})$ and $14(4.9 \mathrm{mg})$. The subfraction F7-5 was purified by Sephadex LH-20 column (MeOH) to afford compound $3(5.5 \mathrm{mg})$ and $\mathbf{6}(7.8 \mathrm{mg})$. The fraction $\mathrm{F} 8$ (17.6 g, eluted by $\mathrm{CH}_{2} \mathrm{Cl}_{2}-\mathrm{MeOH}$ 10:1) was further separated using RP- $\mathrm{C}_{18} \mathrm{CC}\left(\mathrm{MeOH}-\mathrm{H}_{2} \mathrm{O}, 20: 80\right.$ to 50:50) to give eight subfractions F8-1F8-8. After further purification with Sephadex LH-20 column $(\mathrm{MeOH})$, the subfraction F8-1 gave compounds 2 (3.1 mg) and $\mathbf{1 1}(6.2 \mathrm{mg})$, and the subfractions F8-2, F8-4, F8-5 gave compounds $\mathbf{5}$ (3.1 $\mathrm{mg}), \mathbf{6}(4.8 \mathrm{mg}), \mathbf{1 6}(5.4 \mathrm{mg})$, respectively. The subfraction F8-8 was chromatographed through a RP$\mathrm{C}_{18} \mathrm{CC}$ eluted with $\mathrm{MeOH}-\mathrm{H}_{2} \mathrm{O}(25: 75)$ to afford compounds $\mathbf{9}(6.4 \mathrm{mg})$ and $\mathbf{1 0}(4.9 \mathrm{mg})$.

Compound 1: Colorless syrup. $[\alpha]_{\mathrm{D}}^{20}+15^{\circ}(\mathrm{c} 0.4, \mathrm{MeOH}) . \mathrm{IR}(\mathrm{KBr}) v_{\max } 3316,2921,2852,1737,1513$, 1444, 1367, 1243, $1074 \mathrm{~cm}^{-1}$. UV $\lambda_{\max }(\mathrm{MeOH}) \mathrm{nm}(\log \varepsilon): 224$ (3.7), 278 (3.0). HRESIMS $\mathrm{m} / z$ $351.1064[\mathrm{M}+\mathrm{Na}]^{+}$(calcd for $\left.\mathrm{C}_{15} \mathrm{H}_{20} \mathrm{O}_{8} \mathrm{Na}, 351.1056\right) .{ }^{1} \mathrm{H}-\mathrm{NMR}\left(\mathrm{CD}_{3} \mathrm{OD}, 400 \mathrm{MHz}\right) \delta: 7.03(2 \mathrm{H}, \mathrm{d}, J$ $\left.=6.8 \mathrm{~Hz}, \mathrm{H}-2^{\prime}, \mathrm{H}^{-} 6^{\prime}\right), 6.68\left(2 \mathrm{H}, \mathrm{d}, J=6.8 \mathrm{~Hz}, \mathrm{H}-3^{\prime}, \mathrm{H}^{\prime} 5^{\prime}\right), 5.45(1 \mathrm{H}, \mathrm{d}, J=8.0 \mathrm{~Hz}, \mathrm{H}-1), 4.47(1 \mathrm{H}$, $\mathrm{dd}, J=12.0,0.8 \mathrm{~Hz}, \mathrm{H}-6 \mathrm{a}), 4.32(1 \mathrm{H}, \mathrm{dd}, J=12.0,5.2 \mathrm{~Hz}, \mathrm{H}-6 \mathrm{~b}), 3.59(1 \mathrm{H}, \mathrm{ddd}, J=5.2,0.8 \mathrm{~Hz}, \mathrm{H}-$ 5), $3.42(1 \mathrm{H}, \mathrm{dd}, J=9.2,9.2 \mathrm{~Hz}, \mathrm{H}-3), 3.36(1 \mathrm{H}, \mathrm{dd}, J=9.2,9.2 \mathrm{~Hz}, \mathrm{H}-4), 3.34(1 \mathrm{H}, \mathrm{dd}, J=9.2,8.0$ $\mathrm{Hz}, \mathrm{H}-2), 2.84$ (2H, t, $\left.J=8.0 \mathrm{~Hz}, \mathrm{H}-7^{\prime}\right), 2.65$ (2H, t, $\left.J=8.0 \mathrm{~Hz}, \mathrm{H}-8^{\prime}\right) .{ }^{13} \mathrm{C}-\mathrm{NMR}\left(\mathrm{CD}_{3} \mathrm{OD}, 100 \mathrm{MHz}\right)$

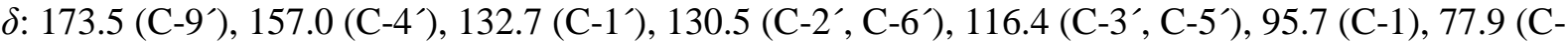
3), 76.1 (C-5), 74.0 (C-2), 71.3 (C-4), 65.9 (C-6), 37.3 (C-8'), 30.9 (C-7').

\subsection{Enzymatic Hydrolysis of Compound 1}

The enzymatic hydrolysis of compound 1 was achieved according to the literature procedures [11]. To a solution of compound $\mathbf{1}\left(10.2 \mathrm{mg}\right.$ ) in $2 \mathrm{~mL}$ of $\mathrm{H}_{2} \mathrm{O}$ was added $\beta$-glucosidase (40 $\mathrm{mg}$, CAS: 9001-22-3), and the reaction mixture was stirred at room temperature overnight. After $14 \mathrm{~h}$, the reaction mixture was extracted with EtOAc, washed with water, dried by $\mathrm{Na}_{2} \mathrm{SO}_{4}$, concentrated under vacuum, and purified to give 4-hydroxyphenyl propionic acid (1a) as the aglycone.

4-Hydroxyphenyl propionic acid (1a) [12]: Amorphous powder. ${ }^{1} \mathrm{H}-\mathrm{NMR}\left(\mathrm{CD}_{3} \mathrm{OD}, 400 \mathrm{MHz}\right) \delta$ : 7.01 $(2 \mathrm{H}, \mathrm{d}, 8.0, \mathrm{H}-2, \mathrm{H}-6), 6.68(2 \mathrm{H}, \mathrm{d}, 8.0, \mathrm{H}-3, \mathrm{H}-5), 2.80(2 \mathrm{H}, \mathrm{t}, 8.0, \mathrm{H}-7), 2.53(2 \mathrm{H}, \mathrm{t}, 8.0, \mathrm{H}-8) ;{ }^{13} \mathrm{C}-$ NMR $\left(\mathrm{CD}_{3} \mathrm{OD}, 100 \mathrm{MHz}\right) \delta$ : 177.1 (C-9), 156.9 (C-4), 133.1 (C-1), 130.4 (C-2, C-6), 116.3 (C-3, C-6), 37.3 (C-8), 31.4 (C-7). 


\subsection{Mushroom Tyrosinase Inhibition Assay}

Mushroom tyrosinase inhibition assay was conducted according to the literature procedures [8]. Arbutin $(25 \mu \mathrm{M})$ was used as the positive control. All experiments were performed three times. The \%inhibition was calculated by $[1-(\mathrm{As} / \mathrm{Ac})] \times 100$, where As is the absorbance of tested compound and Ac the non-treated control. The results were analyzed by program GraphPad Prism 5.0. Data are expressed as means \pm SEMs of triplicate.

\section{Results and Discussion}

\subsection{Isolation and Structure Elucidation}

The air-dried T. giganteum rhizomes were extracted with $95 \%$ EtOH to afford the EtOH extract, which was sequentially fractionated into $\mathrm{CH}_{2} \mathrm{Cl}_{2}, n-\mathrm{BuOH}-$ and $\mathrm{H}_{2} \mathrm{O}$-soluble fractions. The mushroom tyrosinase inhibition assay was employed to evaluate the bioactivities of all crude extracts at a derivative concentration of $100 \mu \mathrm{g} / \mathrm{mL}$. As summarized in Table 1, the $n$-BuOH-soluble fraction showed the best inhibitory activity against mushroom tyrosinase. Therefore, the $n$-BuOH-soluble fraction was chosen for further investigation of its chemical constituents in this study.

Table 1. Inhibitory effects of various fractions obtained from the extract of $T$. giganteum rhizomes and arbutin on mushroom tyrosinase activity ${ }^{[a]}$

\begin{tabular}{lc}
\hline Fraction & Tyrosinase inhibition (\%) \\
\hline Control (100\% DMSO) & $\mathrm{NI}^{\left[{ }^{b]}\right]}$ \\
$95 \%$ EtOH extract & $5.12 \pm 0.77$ \\
$\mathrm{CH}_{2} \mathrm{Cl}_{2}$-Soluble fraction & $8.34 \pm 0.38$ \\
$n-\mathrm{BuOH}-$ Soluble fraction & $13.62 \pm 0.72$ \\
$\mathrm{H}_{2} \mathrm{O}-$ Soluble fraction & $\mathrm{NI}^{[\mathrm{b}]}$ \\
arbutin (positive control) & $38.07 \pm 0.95$ \\
\hline a] Measured at $100 \mu \mathrm{g} / \mathrm{mL}$, using L-tyrosine as the substrate. Results were shown as means \pm SEMs. ${ }^{[\mathrm{b}]} \mathrm{NI}: \mathrm{no}$ \\
inhibition.
\end{tabular}

After repeated column chromatography over silica gel, RP-C18 and Sephadex LH-20, the n$\mathrm{BuOH}$-soluble fraction gave sixteen glycosides (1-16), one of which was a new compound. The fifteen known glycosides (2-16) were identified as 2-(4-hydroxy-3-methoxyphenyl)ethyl- $\beta$-Dglucopyranoside (2) [13], $\beta$-(4-hydroxy-3,5-dimethoxyphenyl)ethyl- $\beta$-D-glucopyranoside (3) [14], 1 $O$-caffeoyl- $\beta$-D-glucopyranose (4) [15], 1- $O$-feruloyl- $\beta$-D-glucopyranose (5) [15], coniferin (6) [16], butylconiferin (7) [17], 2-methoxy-4-vinylphenol glycoside (8) [18], vanilloloside (9) [19], isotachioside (10) [20], tachioside (11) [21], pinoresinol-4-O-glucopyranoside (12) [22], lasianthionosides A (13) [23], byzantionoside B (14) [24], $(6 S, 9 R)$-roseoside (15) [25], 3 $\beta$ - $O$ - $(\beta$-Dglucopyranosyloxyl)-megastigma-9-one (16) [26], respectively, by spectral comparison with literature. All compounds were reported from $T$. giganteum for the first time. The structure of the new compound (1) was elucidated on the basis of spectroscopic analysis, enzymatic hydrolysis and comparison with literature as described below.

Compound 1 was obtained as a colorless syrup. The molecular formula $\mathrm{C}_{15} \mathrm{H}_{20} \mathrm{O}_{8}$, with six degrees of unsaturations, was established based on its quasi-molecular ion peak at $m / z, 351.1064[\mathrm{M}+$ Na] ${ }^{+}$(calcd for $\mathrm{C}_{15} \mathrm{H}_{20} \mathrm{O}_{8} \mathrm{Na}, 351.1056$ ) in the HRESIMS spectrum. The IR absorption bands at 1737 and $3316 \mathrm{~cm}^{-1}$ suggested the presence of a carbonyl group and hydroxyl groups. The ${ }^{1} \mathrm{H}-\mathrm{NMR}$ spectrum of 1 revealed the signals of an $\mathrm{AA}^{\prime} \mathrm{BB}^{\prime}$ spin system at $\delta 7.03\left(2 \mathrm{H}, \mathrm{d}, J=6.8 \mathrm{~Hz}, \mathrm{H}-2^{\prime}, \mathrm{H}-6^{\prime}\right)$, $6.68\left(2 \mathrm{H}, \mathrm{d}, J=6.8 \mathrm{~Hz}, \mathrm{H}-3^{\prime}, \mathrm{H}-5^{\prime}\right)$, suggesting the presence of one para-disubstituted benzene ring. Its ${ }^{13} \mathrm{C}$ NMR and DEPT spectra showed the signals of six aromatic carbons (two signals at $\delta 130.5$ and 116.4 appearing as double intensity), one quaternary carbon $(\delta 173.5)$, two methylene carbons $(\delta 37.3$, 30.9 ), which suggested the presence of 4-hydroxyhydrocinnamoyl group. The proton signals at $\delta_{\mathrm{H}} 5.45$ 
Isolation and characterization glycosidic tyrosinase inhibitors

$(1 \mathrm{H}, \mathrm{d}, J=8.0 \mathrm{~Hz}, \mathrm{H}-1), 4.47(1 \mathrm{H}, \mathrm{dd}, J=12.0,0.8 \mathrm{~Hz}, \mathrm{H}-6 \mathrm{a}), 4.32(1 \mathrm{H}, \mathrm{dd}, J=12.0,5.2 \mathrm{~Hz}, \mathrm{H}-6 \mathrm{~b})$, $3.59(1 \mathrm{H}$, ddd, $J=5.2,0.8 \mathrm{~Hz}, \mathrm{H}-5), 3.42(1 \mathrm{H}, \mathrm{dd}, J=9.2,9.2 \mathrm{~Hz}, \mathrm{H}-3), 3.36(1 \mathrm{H}, \mathrm{dd}, J=9.2,9.2 \mathrm{~Hz}$, $\mathrm{H}-4), 3.34(1 \mathrm{H}, \mathrm{dd}, J=9.2,8.0 \mathrm{~Hz}, \mathrm{H}-2)$, and ${ }^{13} \mathrm{C}-\mathrm{NMR}$ signals at $\delta_{\mathrm{C}} 95.7(\mathrm{C}-1), 77.9(\mathrm{C}-3), 76.1(\mathrm{C}-$ 5), 74.0 (C-2), 71.3 (C-4), 65.9 (C-6) demonstrated the presence of a glucose. The speculations above were confirmed by the key ${ }^{1} \mathrm{H}^{-1} \mathrm{H}$ COSY and HMBC correlations shown in Figure 2. The sugar moiety was decided as $\beta$-glucose $\left(J_{1,2}=8.0 \mathrm{~Hz}\right)$ and elucidated as D-sugar by subsequent enzymatic hydrolysis. The HMBC correlations from H-1 to C-9' suggested that the 4-hydroxyphenyl propionic acid was attached to $\mathrm{C}-1$ position of the sugar moiety. Therefore, the structure of compound 1 was identified as 1-O-(4-hydroxyhydrocinnamoyl)- $\beta$-D-glucopyranose. Although searching the structure of 1 in Scifinder database gave a similar structure (CAS: 2569469-61-8) and one literature [27], further investigation of the original reference could not find the target compound. Therefore, compound $\mathbf{1}$ is still determinated as a new compound.

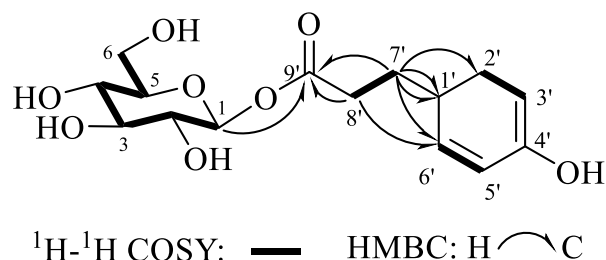

Figure 2. Key ${ }^{1} \mathrm{H}-{ }^{1} \mathrm{H}$ COSY and $\mathrm{HMBC}$ correlations for compound 1

\subsection{Tyrosinase Inhibitory Activity}

All isolated compounds 1-16 were evaluated for their tyrosinase inhibitory activities at a concentration of $25 \mu \mathrm{M}$, using arbutin as the positive control. The results were summarized in Table 2 . Compounds 10 and 11 showed obvious inhibitory activities, with \%inhibition values of $20.94 \pm 0.59 \%$, $23.28 \pm 1.09 \%$, respectively, close to the known melanogenesis inhibitor, arbutin (4-hydroxyphenyl $\beta$ D-glucopyranoside; $26.21 \pm 0.58 \%$ ), which has been used as an effective skin-whitening agent in the cosmetic industry [28]. However, their analogues 6-9 showed weaker inhibitory activities. Other compounds showed weak or no inhibitory activities (\%inhibition $<5 \%$ ). Among the compounds tested, the structures of 6-11 possess a high similarity to arbutin. Therefore, a simple structure activity relationship of arbutin and its analogues 6-11 was discussed in Figure 3. The results indicate that groups at C-2, C-4, and C-5 in arbutin are important factors for inhibitory activity against tyrosinase. The electron-donating substituents at C-2 (10) or C-5 (11) lead to increased inhibitory activities, and replacing the hydroxyl group at C-4 in arbutin with electron-donating groups such as vinyl (8) or others $(\mathbf{6}, \mathbf{7}, \mathbf{9})$ lead to a sharp decrease of inhibitory activities. Among these, isotachioside (10) and tachioside (11) have been demonstrated to be the most relevant principles of the tyrosinase inhibitory activity of the extract, and these glycosidic analogues of arbutin 6-11 isolated from Typhonium giganteum rhizomes in this study may be valuable as potential skin-whitening agents.

Table 2. Inhibitory effects of compounds 4, 6-11 and of arbutin on mushroom tyrosinase $\mathrm{e}^{[\mathrm{a}]}$

\begin{tabular}{cc} 
Compound & Tyrosinase inhibition (\%) \\
\hline $\mathbf{4}$ & $5.27 \pm 0.74$ \\
$\mathbf{6}$ & $10.54 \pm 0.81$ \\
$\mathbf{7}$ & $7.17 \pm 0.85$ \\
$\mathbf{8}$ & $14.20 \pm 0.84$ \\
$\mathbf{9}$ & $12.44 \pm 1.11$ \\
$\mathbf{1 0}$ & $20.94 \pm 0.59$ \\
$\mathbf{1 1}$ & $23.28 \pm 1.09$ \\
arbutin (positive control) & $26.21 \pm 0.58$ \\
\hline
\end{tabular}

${ }^{\text {a] }}$ Measured at $25 \mu \mathrm{M}$, using L-tyrosine as the substrate. Results were expressed as means \pm SEMs. 




$10.54 \pm 0.81 \%$

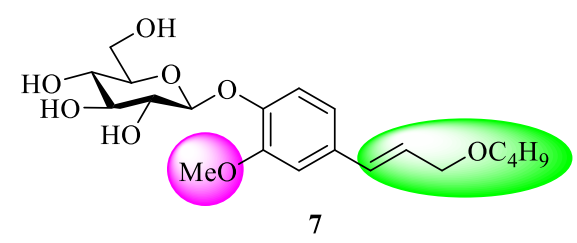

$7.17 \pm 0.85 \%$

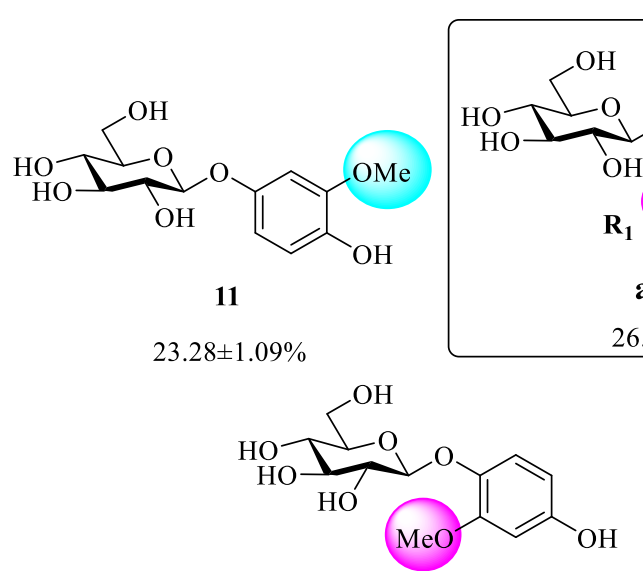

10

$20.94 \pm 0.59 \%$
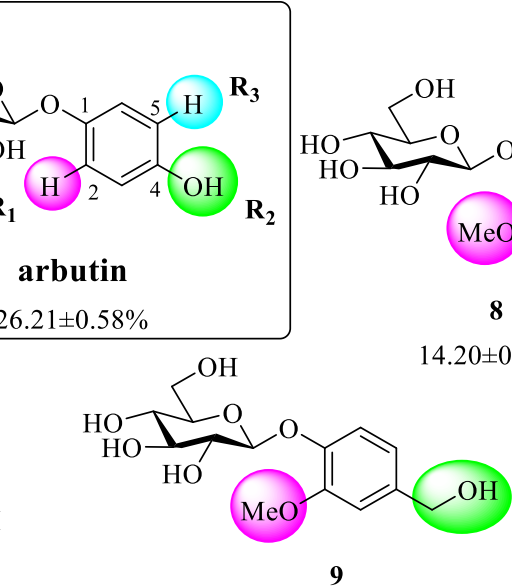

9

Figure 3. Structure activity relationship of arbutin analogues as tyrosinase inhibitors

\section{Acknowledgments}

We thank Lanxiang Dai for the collection of Typhonium giganteum rhizomes and Prof. Lin Yang for the identification of the plant material. This work was financially supported by National Natural Science Foundation of China (21702178), Project of Science and Technology Department of Henan Province (212102311031), National Undergraduate Training Program for Innovation and Entrepreneurship (202010480003) and Distinguished Young Scholars Fund of Xuchang University (2019).

\section{Supporting Information}

Supporting information accompanies this paper on http://www.acgpubs.org/journal/records-ofnatural-products

\section{ORCID}

Penghua Shu: 0000-0001-6018-8429

Huiqing Zhu: $0000-0001-5070-4856$

Wanrong Liu: 0000-0002-0503-0554

Lingxiang Zhang: 0000-0001-7802-5767

Junping Li: 0000-0001-9875-0819

Mengzhu Yu: 0000-0001-6922-1598

Yingying Fei: $\underline{0000-0003-4372-9160}$

Shujing Cai: 0000-0001-7477-0700

Ruihua Li: 0000-0002-1328-6007

Xialan Wei: 0000-0003-0661-0929

Wenhan Yi: 0000-0001-9995-9155

Fugang Xiao: 0000-0003-3024-6987 
Isolation and characterization glycosidic tyrosinase inhibitors

\section{References}

[1] Chinese Pharmacopeia Commission (2020). Pharmacopoeia of the People's Republic of China (Vol. 1). China Medical Science Press, Beijing, pp. 110-111.

[2] Y.L Li, L. Zhong and L.H. Liang (2002). The experimental studies of six kinds of Chinese medicines inhibiting tyrosinase activity, Shizhen Guoyi Guoyao 13, 129-131.

[3] Y. Ye, G.X. Chou, D.D. Mu, H. Wang, J.H. Chu, A.K.M. Leung, W.F. Fong and Z.L. Yu (2010). Screening of Chinese herbal medicines for antityrosinase activity in a cell free system and B16 cells, $J$. Ethnopharmacol. 129, 387-390.

[4] K.-W. Liu, Z.-L. Li, S.-B. Pu, D.-R. Xu, H.-H. Zhou and W.-B. Shen (2014). Chemical constituents of the rhizome of Typhonium giganteum, Chem. Nat. Compd. 50, 1079-1081.

[5] Y. Jin, J.-T. Fan, X.-L. Gu, L.-Y. Zhang, J. Han, S.-H. Du and A.-X. Zhang (2017). Neuroprotective activity of cerebrosides from Typhonium giganteum by regulating caspase-3 and Bax/Bcl-2 signaling pathways in PC12 cells, J. Nat. Prod. 80, 1734-1741.

[6] X.S. Chen, D.H. Chen, J.Y. Si and G.Z. Tu (2001). Chemical constituents of Typhonium giganteum Engl, J. Asian Nat. Prod. Res. 3, 277-283.

[7] P. Shu, Y. Fei, J. Li, A. Liu, L. Zhang, H. Niu, W. Liu, X. Wei, F. Xiao and Z. Xu (2020). Two new phenylethanoid glycosides from Ginkgo biloba leaves and their tyrosinase inhibitory activities, Carbohydr. Res. 494, 108059.

[8] P. Shu, J. Li, Y. Fei, H. Zhu, M. Yu, A. Liu, H. Niu, S. Zou, X. Wei, Z. Ju and Z. Xu (2020). Isolation, structure elucidation, tyrosinase inhibitory, and antioxidant evaluation of the constituents from Angelica dahurica roots, J. Nat. Med. 74, 456-462.

[9] P. Shu, J. Li, Y. Fei, H. Zhu, L. Zhang, H. Niu, Y. Li, H. Liu, Z. Ju, X. Wei, F. Xiao and Z. Xu (2020). Angelicosides I-IV, four undescribed furanocoumarin glycosides from Angelica dahurica roots and their tyrosinase inhibitory activities, Phytochem. Lett. 36, 32-36.

[10] P. Shu, L. Zhang, W. Liu, Y. Fei, M. Sun, Y. Lou, A. Liu, M. Yu, J. Li, X. Wei and N. Sun (2021). Chemical constituents from Typhonium giganteum rhizome and their antioxidant, tyrosinase inhibitory activities, Rec. Nat. Prod. 15, 53-58.

[11] P. Shu, M. Sun, J. Li, L. Zhang, H. Xu, Y. Lou, Z. Ju, X. Wei, W. Wu and N. Sun (2020). Chemical constituents from Ginkgo biloba leaves and their cytotoxicity activity, J. Nat. Med. 74, 269-274.

[12] C. Peng, Y. Liu, X. Guo, W. Liu, Q. Li and Z.K. Zhao (2018). Selective carboxylation of substituted phenols with engineered escherichia coli whole-cells, Tetrahedron Lett. 59, 3810-3815.

[13] B.-Q. Zhu, J.-F. Yang, T.-T. Song, X.-F. Li, T. Guo, L.-L. Wang, Y. Wang and J. Chang (2020). Chemical constituents of Zanthoxylum bungeanum (2020), Chem. Nat. Compd. 56, 164-165.

[14] E. Horvathova, M. Mastihubova, E.K. Potocka, P. Kis, E. Galova, A. Sevcovicova, M. Klapakova, L. Hunakova and V. Mastihuba (2019). Comparative study of relationship between structure of phenylethanoid glycopyranosides and their activities using cell-free assays and human cells cultured in vitro, Toxicol. In Vitro. 61, 104646.

[15] Y. Sun, Y. Liu, Y.-P. Sun, H.-L. Ye, J. Pan, W. Guan, B.-Y. Yang and H.-X. Kuang (2020). Lanicepsides CE from the aerial part of Clematis chinensis Osbeck, Phytochem. Lett. 37, 95-100.

[16] Q. Liu, Y.-J. Zhang, C.-R. Yang and M. Xu (2009). Phenolic Antioxidants from green tea produced from Camellia crassicolumna Var. multiplex, J. Agric. Food Chem. 57, 586-590.

[17] Z. Dai, G.-L. Wang and R.-C. Lin (2006). Chemical constituents of Balanophora simaoensis (III), Zhongcaoyao 37, 1608-1610.

[18] S. Fukai, S. Tanimoto, A. Maeda, H. Fukuda, Y. Okada and M. Nomura (2009). Pharmacological activity of compounds extracted from persimmon peel (Diospyros kaki Thunb.), J. Oleo Sci. 58, 213-219.

[19] W. Peng, X. Fu, Y. Li, Z. Xiong, X. Shi, F. Zhang, G. Huo and B. Li (2019). Phytochemical study of stem and leaf of Clausena lansium, Molecules 24, 3124.

[20] T. Matsumoto, T. Nakajima, T. Iwadate and K.-I. Nihei (2018). Chemical synthesis and tyrosinaseinhibitory activity of isotachioside and its related glycosides, Carbohydr. Res. 465, 22-28.

[21] D. Wang, Y. Wang, S.-B. Tan, T. Guo, A.-H. Zhao and J. Chang (2019). Phenol glycosides and flavonol glycosides from the aerial part of Zingiber officinale, Chem. Nat. Compd. 55, 540-541.

[22] X.-C. Zhao, J.-L. Du, Y.-G. Xie, Y. Zhang and H.-Z. Jin (2018). Chemical constituents of the flowers of Hemerocallis minor, Chem. Nat. Compd. 54, 556-558.

[23] Y. Takeda, H. Shimizu, T. Masuda, E. Hirata, T. Shinzato, M. Bando and H. Otsuka (2004). Lasianthionosides A-C, megastigmane glucosides from leaves of Lasianthus fordii, Phytochemistry $\mathbf{6 5}$, 485-489. 
[24] K. Matsunami, H. Otsuka and Y. Takeda (2010). Structural revisions of blumenol C glucoside and byzantionoside B, Chem. Pharm. Bull. 58, 438-441.

[25] X. Jia, D. Yang, Y. Yang and H. Xie (2019). Carotenoid-derived flavor precursors from Averrhoa carambola fresh fruit, Molecules 24, 256.

[26] Q.X. Zheng, Z.J. Xu, X.F. Sun, W. Yao, H.D. Sun, C.H.K. Cheng and Y. Zhao (2003). Eudesmane and megastigmane glucosides from Laggera alata, Phytochemistry 63, 835-839.

[27] E.-M. Tomou and H. Skaltsa (2018). Phytochemical investigation of the fern Asplenium ceterach (Aspleniaceae), Nat. Prod. Commun. 13, 849-850.

[28] P. Migas and M. Krauze-Baranowska (2015). The significance of arbutin and its derivatives in therapy and cosmetics, Phytochem. Lett. 13, 35-40.

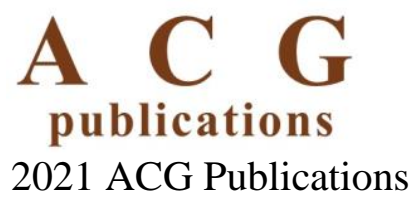

